\title{
Peran Dukungan Suami Terhadap Kecenderungan Depresi Paska Melahirkan
}

\section{The Role of Husband Support to The Tendency of Postpartum Depression}

KATA KUNCI

KEYWORDS

ABSTRAK

ABSTRACT
Depresi Paska Melahirkan, Dukungan Suami

Postpartum Depression, Husband Support

Penelitian ini bertujuan untuk mengetahui peran dukungan suami terhadap kecenderungan depresi paska melahirkan. Penelitian menggunakan pendekatan kuantitatif dengan alat ukur yang digunakan adalah Edinburgh Postnatal Depression Scale (EPDS) untuk mengukur depresi paska melahirkan dan Postpartum Social Support Questionnaire (PSSQ) untuk mengukur dukungan suami. Partisipan dalam penelitian ini adalah wanita yang sudah pernah melahirkan dan memiliki anak usia maksimal 1 tahun di wilayah Bogor dan Depok. Teknik analisis data yang digunakan adalah regresi linear sederhana. Hasilnya menunjukkan dukungan suami berkontribusi signifikan $\left(\mathrm{R}^{2}=0,044 ; \mathrm{p}<0,05\right)$ terhadap kecenderungan depresi paska melahirkan.

This study aims to determine the role of husband support for the prevalence of postpartum depression. This research used quantitative approach and the tools were Edinburgh Postnatal Depression Scale (EPDS) to measure postpartum depression and Postpartum Social Support Questionnaire (PSSQ) to measure husband support. Only women who had a birth experience and child under 12 months would be participants. This study resulted husband support has a significant contribution $\left(R^{2}=0,044 ; \mathrm{p}<0,05\right)$ to postpartum depression.

\section{PENDAHULUAN}

Kehamilan dan persalinan merupakan tahap perkembangan normal yang harus dijalani oleh seorang wanita. Periode paska persalinan merupakan fase transisi dari perubahan fisik dan psikologis ibu yang seringkali berdampak buruk bagi kehidupannya.

Beberapa kasus yang menjadi perhatian masyarakat luas mengenai seorang ibu dengan bayinya, seperti dalam kasus yang ditulis oleh Sinulingga (2013) menyatakan ada ibu yang tega membunuh bayinya sendiri dan dicurigai mengalami gangguan depresi. Lain lagi yang ditulis oleh Agrina (2018) tentang ibu yang meninggalkan bayinya di toilet umum bandara karena merasa tidak mampu dan layak menjaga bayinya.

Ibu yang baru pertama kali memiliki anak akan mengalami kecemasan dan ketakutan saat bayinya lahir karena sang ibu memiliki pengalaman serta pengetahuan yang minim soal bayi yang baru lahir yang dapat membuat sang ibu jadi mudah bingung. 
Namun apabila gejala tersebut terus muncul lebih dari empat minggu, maka ada kemungkinan ibu mengalami depresi paska melahirkan (Serhan, Ege, Ayranci \& Kosgeroglu, 2012).

Menurut Nevid, Rathus dan Greene (2005) depresi paska melahirkan merupakan perubahan mood yang sering muncul setelah melahirkan. Gejala dari depresi paska melahirkan meliputi perasaan sedih, perubahan mood, kekurangan energi, kehilangan minat, kehilangan nafsu makan, benci pada diri sendiri, memiliki pemikiran untuk bunuh diri dan kehilangan konsentrasi (Rosenthal, 2000). Nurbaeti (2018) menyatakan bahwa prevalensi kejadian depresi paska melahirkan yang ada di Indonesia adalah sekitar 18,37\%. Lebih lanjut, depresi yang dialami ibu akan menurunkan kemampuan anak dalam mengembangkan kemampuan intelektual dan motorik, kemampuan emosional dan sosial, dan membuat anak merasa kurang aman dan lekat dengan ibunya (Pradly \& Kieman, 2012; Nielsen \& Krogh, 2016).

$$
\text { Dukungan sosial diprediksi }
$$

menurunkan prevalensi ibu mengalami depresi usai melahirkan (Urbayatun, 2010). Secara spesifik, dukungan keluarga memiliki hubungan dengan risiko mengalami depresi paska melahirkan (Nasri, Wibowo, \& Ghozali, 2017). Menurut Sarafino (2006), dukungan sosial adalah kenyamanan, perhatian, penghargaaan yang dirasakan atau bantuan yang diterima dari orang lain atau kelompok. Menurut Hopkins dan Campbell (2008), dukungan sosial dapat berasal dari dukungan orangtua dan mertua; dukungan keluarga; dukungan teman; serta dukungan dari pasangan.

Ibu yang baru saja melahirkan akan sangat membutuhkan dukungan atau respon positif dari suami. Suami merupakan dukungan pertama atau utama dalam memberikan dukungan sosial kepada istri karena suami adalah orang pertama yang menyadari adanya perubahan fisik dan psikis istrinya (Oktaputrining dkk, 2017). Dukungan suami adalah salah satu bentuk interaksi yang didalamnya terdapat hubungan yang saling memberi dan menerima bantuan yang bersifat nyata yang dilakukan oleh suami terhadap istrinya (Oktalina, Muniroh, \& Adiningsih, 2015). Secara psikologis dukungan suami, membuat istrinya merasa nyaman, berharga, dibutuhkan, sehingga timbul rasa kuat dan semangat, bahagia dan percaya diri menghadapi proses kehamilan dan persalinan (Fairus \& Widiyanti, 2014). Penelitian ini ingin melihat hubungan dukungan suami dengan kecenderungan depresi paska melahirkan; serta kontribusi peran dukungan suami terhadap kecenderungan wanita mengalami depresi usai melahirkan.

\section{METODE PENELITIAN}

Variabel yang digunakan dalam penelitian ini adalah depresi paska melahirkan dan dukungan suami.

\section{Partisipan Penelitian}

Sampel yang digunakan dalam penelitian ini adalah perempuan yang memiliki anak berusia maksimal satu tahun. Sampel diperoleh dengan cara datang mengunjungi pusat layanan kesehatan, seperti Puskesmas dan Klinik Bidan Mandiri di wilayah Depok dan Bogor sesuai dengan balasan surat ijin meneliti yang hanya diperoleh dari dua wilayah tersebut.

\section{Prosedur Penelitian}

Ketika mendatangi pusat kesehatan yang merupakan lokasi pengambilan data, peneliti mendatangi wanita yang sedang menunggu antrian untuk konsultasi baik konsultasi ke bidan maupun ke dokter. Seluruh partisipan yang terlibat hanyalah yang bersedia karena di awal peneliti memberikan gambaran terhadap pertanyaanpertanyaan yang akan diajukan. Walaupun jumlah partisipan yang terlibat sebanyak 252, hanya 157 partisipan yang diolah datanya karena hanya sejumlah 157 yang memiliki skor pada alat ukur EPDS $>9$ yang merupakan nilai minimum seseorang dikatakan mengalami kecenderungan depresi usai melahirkan. 


\section{Instrumen Penelitian}

\section{Skala Depresi Paska Melahirkan}

Pengukuran depresi paska melahirkan ini menggunakan alat ukur yang diadaptasi dari Edinburgh Postnatal Depression Scale (EPDS) ke dalam bahasa Indonesia. Dalam penelitian ini, peneliti menggunakan alat ukur EPDS. EPDS merupakan instrumen skrinning yang telah digunakan dari waktu ke waktu dalam periode paska melahirkan. 10 item EPDS adalah salah satu yang paling banyak digunakan dalan pengukuran self-report depresi paska melahirkan.

EPDS berupa kuesioner yang terdiri dari 10 item pertanyaan yang di dalamnya terdapat item favorable dan item unfavorable dengan empat pilihan jawaban. Dalam penelitian ini, peneliti menggunakan tiga dimensi EPDS. Dalam penelitian ini EPDS memiliki nilai alpha cronbach 0,711 .

\section{Skala Dukungan Suami}

Pengukuran yang digunakan adalah alat ukur yang dibuat oleh Hopkins dan Campbell (2008) yaitu Postpartum Social Support Questionnaire (PSSQ). PSSQ dikembangkan untuk menyediakan laporan mandiri yang komprehensif dari dukungan sosial selama periode paska melahirkan. Tujuan lainnya dalam instrumen ini adalah untuk menilai aspek dukungan sosial khusus untuk periode paska melahirkan. PSSQ ini berupa kuesioner yang terdiri dari 15 item pernyataan dari subscales partner support. Dalam penelitian ini PSSQ memiliki nilai alpha croncbach 0,669 .

Terdapat 12 item dalam PSSQ dijawab dengan menggunakan skala Likert dengan 7 alternatif pilihan jawaban yang disusun, yakni dari 1
"Hampir Tidak Pernah" sampai 7 "Sangat Sering".

\section{Metode Analisis Data}

Analisis data yang digunakan dalam penelitian ini menggunakan teknik regresi linear sederhana. Sebelum melakukan pengujian regresi dilakukan uji normalitas. Hasil uji normalitas menunjukkan bahwa distribusi data penelitian bersifat normal dengan nilai $p=0,686(p>0,05)$. Oleh karena data berdistribusi normal, pengujian statistik dengan menggunakan analisis parametrik dapat dilakukan, yaitu menggunakan teknik analisis regresi sederhana.

\section{ANALISIS dan HASIL}

Ada 157 wanita yang berpartisipasi dalam penelitian ini dengan rata-rata usia adalah 30 tahun $(\mathrm{SD}=5,4)$ dengan rentang usia 18-40 tahun. Partisipan yang datanya diolah didominasi oleh wanita dengan pendidikan terakhir adalah SMA (70\%), tidak bekerja (72\%), dan menyusui secara penuh $(71 \%)$. Berdasarkan norma kategorisasi data hasil penelitian diketahui bahwa kecenderungan depresi paska melahirkan berada di kategori mild (atau depresi ringan) sebanyak $52,9 \%$.

Hasil penelitian ini menemukan bahwa nilai korelasi antara depresi paska melahirkan dengan dukungan suami adalah signifikan, yakni sebesar 0,209 dengan arah korelasi negatif $(\mathrm{p}<0,05)$. Artinya adalah semakin tinggi dukungan yang diberikan oleh suami, maka prevalensi depresi paska melahirkan semakin rendah. Lebih lanjut hasil uji regresi linear nilai $\mathrm{R}^{2}$ yang diperoleh sebesar $0,044 \quad(p<0,05)$. Hal ini menunjukkan bahwa sebesar $4,4 \%$ variabel dukungan sosial suami berkontribusi dalam memprediksi depresi paska melahirkan, sementara sisanya sebesar 95,6\% dipengaruhi oleh variabel lain yang tidak dimasukkan dan dibahas dalam penelitian ini. 


\section{DISKUSI}

Tujuan utama dari penelitian ini adalah untuk mengetahui apakah ada peran dukungan suami yang signifikan terhadap kecenderungan depresi paska melahirkan pada perempuan. Hasil penelitian ini mendukung hipotesis penelitian yang menunjukkan bahwa ada peran dukungan suami yang signifikan terhadap kecenderungan depresi paska melahirkan pada perempuan. Artinya adalah perempuan yang baru melahirkan dan memiliki suami yang memberikan dukungan cenderung mengalami depresi paska melahirkan dengan tingkat yang rendah.

Temuan tersebut didukung oleh penelitian yang dilakukan oleh Kazmi dkk (2013) yang menyatakan bahwa dukungan sosial suami dengan depresi paska melahirkan memiliki hubungan yang signifikan. Penelitian selanjutnya dari Gregmini (2011) menyatakan bahwa dukungan suami berkontribusi untuk gejala depresi paska melahirkan. Penelitian lainnya dari Haryani dan Gusniarty (2007) yang menyatakan bahwa semakin positif dukungan yang diberikan oleh suami maka semakin rendah kecenderungan depresi paska melahirkan. Artinya penelitian sebelumnya mendukung hasil dalam penelitian ini, dimana semakin tinggi peran dukungan suami yang diberikan, maka risiko terjadinya kecenderungan depresi paska melahirkan akan menurun.

Berdasarkan penelitian sebelumnya ada beberapa faktor lainnya yang dapat mempengaruhi kecenderungan terjadinya depresi paska melahirkan, seperti dalam penelitian Nurbaeti (2018), faktor lainnya yang kemungkinan mempengaruhi depresi paska melahirkan adalah faktor yang berhubungan dengan bayi, marital relationship, serta childcare stress.

Hasil penelitian lainnya dari AlModayfer dkk (2015) menunjukkan faktor yang mempengaruhi risiko depresi paska melahirkan adalah berdasarkan waktu kelahiran, kesehatan ibu selama kehamilan dan riwayat penyakit kejiwaan sebelumnya.
Selain itu, penelitian dari Nasri, Wibowo dan Ghozali (2017) menyatakan bahwa dukungan keluarga merupakan faktor yang mempengaruhi terjadinya depresi paska melahirkan.

Temuan tersebut didukung oleh penelitian sebelumnya dari Saligheh dkk (2014) yang menyatakan bahwa tidak ada satu pun dari faktor sosiodemografi, seperti usia ibu, jumlah anak,dan tingkat pendidikan yang dapat memprediksi tingkat terjadinya risiko depresi paska melahirkan.

Penelitian lainnya dari Hanifah (2017) menunjukkan bahwa tidak ada hubungan antara usia ibu, paritas, pendidikan dan pekerjaan dengan kejadian depresi paska melahirkan. Penelitian selanjutnya yang mendukung adalah dari Al-Modayfer dkk (2015) menyatakan bahwa tidak ada perbedaan yang signifikan antara faktor demografi (seperti usia, pendidikan, pekerjaan, riwayat kelahiran) dengan kejadian depresi paska melahirkan.

Di sisi lain, masih terdapat beberapa kekurangan dalam proses penelitian ini yaitu mengenai kesulitan dalam menentukan cut of point seseorang yang tergolong depresi paska melahirkan karena belum terdapat kesepakatan yang jelas di Indonesia dalam menentukan cut of point tersebut.

\section{SIMPULAN}

Hasil penelitian menunjukkan bahwa, ada peran dukungan suami yang signifikan terhadap kecenderungan depresi paska melahirkan pada perempuan. Oleh karena itu, dapat dikatakan bahwa semakin tinggi dukungan suami maka depresi paska melahirkan akan menurun.

\section{SARAN}

Penelitian ini menguji depresi paska melahirkan dengan menggunakan Edinburgh Postnatal Depression Scale (EPDS) yang telah digunakan pada beberapa penelitian sebelumnya dan diketahui valid. Walaupun demikian, masih ada ketidaksepakatan terkait skor minimum (cut of point) untuk menentukan kategori 
depresi paska melahirkan. Penelitian ini menggunakan angka sembilan untuk menetapkan kategori tersebut dengan pertimbangan skor paling rendah yang digunakan selama ini pada beberapa penelitian sebelumnya yang menggunakan partisipan lebih banyak bukan perempuan Indonesia. Oleh karena itu, menjadi hal penting untuk penelitian sebelumnya

\section{DAFTAR PUSTAKA}

Agrina, N. (8 Februari 2018). Melahirkan di airport, Ibu meninggalkan surat sedih bersama bayinya. Diunduh dari https://www.popmama.com/

Fairus, M., dan Widiyanti, S. (2014). Hubungan dukungan suami dengan kejadian depresi postpartum pada ibu nifas. Jurnal Kesehatan Metro Sai Wawai, 7(1), 11-18.

Hanifah, R. S. (2017). Faktor-faktor yang berhubungan dengan kejadian depresi postpartum di wilayah kerja Puskesmas Karanganyar Kabupaten Karanganyar (Skripsi). Universitas Muhammadiyah Surakarta, Surakarta, Jawa Tengah.

Hopkins, J., \& Campbell, S. B. (2008). Development and validation of a scale to assess social support in the postpartum period. Archives of Women's Mental Health, 11(1), 57-65.

Nevid, J.S., Rathus, S.A., \& Greene, B. (2005). Psikologi abnormal. Jakarta: Erlangga

Nurbaeti, I. (2018). Postpartum depression and its predicting factors at one month after birth in Indonesian women. Thai Pharmaceutical and Health Science Journal, 13(1), 19-27.

Oktalina, O., Muniroh, L., \& Adiningsih, S. (2015). Hubungan dukungan suami dan dukungan keluarga dengan pemberian asi eksklusif pada ibu anggota kelompok pendukung asi (KP-ASI). Media Gizi Indonesia. 10(4), 1-7. mencaritahu cut of point paling tepat untuk diterapkan di wilayah Indonesia. Lebih lanjut, partisipan diperoleh di lokasi pusat kesehatan sehingga memanfaatkan waktu tunggu sebelum partisipan mendapatkan giliran berkonsultasi dengan dokter dan bidan sehingga seringkali pengisian kuesioner terputus dan tidak selesai.

Oktaputrining, D., Susandi, C., \& Suroso, S. (2017). Post partum blues: Pentingnya dukungan sosial dan kepuasan pernikahan pada ibu primipara. Psikodimensia, 16(2), 45-51.

Nasri, Z., Wibowo, A., \& Ghozali, E. W. (2017). Faktor determinan depresi postpartum di kabupaten Lombok Timur. Buletin Penelitian Sistem Kesehatan, 20(3), 89-95.

Pradly, S.L., Kieman, K.E. (2012). The effect of post-nata; mental distress among Indian and Pakistani mothers living in England on children's behavioral outcomes. Child Care Health Development, 39(4), 251258.

Rosenthal, M.S. (2000). Women and depression. Los Angeles: McGraw-Hill.

Sarafino, E.P. (2006). Health psychology. New Jersey: John Willey \& Sons.

Serhan, N., Ege, E., Ayranci, U., \& Kosgeroglu, N. (2012). Prevalence of postpartum depression in mothers and fathers and its correlates. Journal of Clinical Nursing, 22(2), 279-284.

Sinulingga, E.A. (10 April 2013). Paska melahirkan, hati-hati dengan Baby Blues. Diunduh dari https://health.detik.com/

Urbayatun, S. (2010). Dukungan sosial dan kecenderungan depresi postpartum pada ibu primipara di daerah gempa Bantul. Jurnal Humanitas, 7(2), 114-122. 